\title{
THE USE TOPOGRAPHIC DATABASE FOR NON STANDART PROJECT
}

\author{
Assist. Prof. Dr. Małgorzata Leszczyńska \\ Senior Lecturer Dr. Servel Miller 2 \\ ${ }^{1}$ University of Warmia and Mazury in Olsztyn, Poland \\ ${ }^{2}$ University of Chester, United Kingdom
}

\begin{abstract}
The touristic maps are the one of the most popular and widely used among the society type of map. However the ones are not official map and no government entity of Poland responsible for producing and distributing this types of maps. Therefore they are not free for local governments.

Tourist on line maps are an ideal way for cities and region to promote their local business community. Indeed, it is estimated that hundred billion is spent on travel and tourism annually in the Poland. This is why local governments spend a large financial outlay for the creation of online tourist maps. But the tourist maps created base on nonstandardized and official source become quickly outdated and update them is expensive.

It seems to be good solution use constantly updated topographic databases for produce tourist maps to promote cities. The one is funded with taxes therefore can be usable without fees for public entities and it is national resource not classified for national security reasons.
\end{abstract}

The series of articles about use topographic database for non-standard project topics will present an algorithm and legal and technological limitations appearing during the attempts to use topographic maps to create online tourist maps base on topographic databases. The article is an introduction to this subject.

Keywords: topographic databases, Spatial Data Infrastructure (SDI)

\section{INTRODUCTION}

New technologies are a source of prosperity. They can offer unquantifiable benefits to both individuals and entire communities. Unfortunately, a drawback of technologically advanced products is their price, which can often significantly exceed the price of a traditional product. Therefore, as far as possible, once a technologically modern product has been manufactured, it should be used repeatedly in order to meet a variety of needs. Digital spatial information collected within the spatial information infrastructure is one of the most technologically advanced products of our age. Its specific advantage is that it can be used repeatedly without being subject to wear and tear over time. There are, however, restrictions on its re-use, namely, its legal, administrative and application aspects.

As regards products manufactured in Poland within the spatial information infrastructure, a key role is served by a topographic object database BDOT10k, with a 
data accuracy and detail level equal to that of topographic maps with a scale of 1:10 000. This database was also the first to cover all of Poland. It contains information on the spatial location of topographic objects and their descriptive attributes. The database was established based on orthophotomap vectorisation, direct measurements and the use of data from bdot500 as well as from other registers maintained by public institutions such as (Cadastral Register, National Database Geodetic Registry of Utility Infrastructure System, National Registry of Boundary, National Registry of Geographical Names, National Official Register of Territorial Divisions). By assumption, the establishment of a topographic object database is intended to limit the repeated acquisition of the same data by various institutions and enterprises, thereby leading to cost and time savings and contributing to the wider use of spatial information in order to enhance the prosperity of the society. The aim of this article and the next articles in this series is to provide answers to the following questions: To what extent have these assumptions been met? Are there still any areas in which the topographic database BDOT10k could be used on a large scale? What are the legal and application opportunities thereof?

\section{TOPOGRAPHIC DATABASE (BDOT10k) - THE CORE OF SDI}

The work on the concept of a topographic database topographic database for the territory of Poland was initiated by the Head Office of Land Surveying and Cartography (GUGiK) in 1998. The problems encountered at that time were as follows: the lack of a uniform standard for the preparation of digital compilations and the lack of a requirement to transfer prepared compilations (digital maps) to the resource. Nevertheless, in 1999, initial experimental work on the establishment of the topographic database was initiated. In March 2003, the first version of technical guidelines [1] providing the basis for the establishment of the nationwide topographic database was issued. These guidelines were replaced by new ones [2] in 2008. The new guidelines (technical guidelines topographic database TBD, version 1.0 supplemented, Appendix No 1, 2008, GUGiK Warszawa [2]) presented for the first time a definition of a topographic database understood as a "uniform, in terms of a conceptual model, official nationwide system for collecting and sharing topographic data, which is comprised, in addition to data, of an appropriate funding system, organisation, IT tools and the necessary technical guidelines and instructions". The guidelines of 2008 [2] provided a basis for the implementation of the project "Geo-referenced Topographic Object Databases GBDOT along with the National Management System". The aim of the project was, inter alia, to establish a Topographic Object Database (BDOT10k) (Georeferenced database) containing information on the location of spatial objects and phenomena throughout the country, to establish a national system for the management of the Topographic Object Database (KSZBDOT) along with a back-up centre, and to enable access to the database through the national geoportal (geoportal.gov.pl). The project's implementation took 6 years, from 25 September 2009 to 30 November 2015. The cost of project's implementation amounted to PLN 176,200,000.00. However, before the project was brought to an end, the content of the topographic database being established had been modified. The modification was due to the establishment in Poland, in 2010 the Infrastructure for Spatial Information (SDI), which was based on the Act on Spatial Information Infrastructure of 4 March 2010 (Journal of Laws of 2010, No 76, Item 489) [6] which provides that "for the territory of the entire country, 
databases shall be established and maintained within an ICT system, which contain sets of spatial data of the spatial information infrastructure, concerning: Topographic objects with a level of detail allowing standard cartographic compilations with a scale from 1:10,000 to 1:100,000 to be prepared". In addition, Article 19(1) of the Act in question introduced a requirement to specify, by way of Regulation, the scope of information to be collected in the topographic object database. A Regulation appropriate for this purpose entered into force on 12 January 2012 [8], and has become the basis for the implementation of the topographic object database BDOT10k (Regulation of Minister of the Interior and Administration of 17 November 2011 on the topographic object database as well as the general geographic object and standard cartographic compilation database Journal of Laws of 2011, No 279, Item 1642) [8]. The topographic object database BDOT10k, established in accordance with that Regulation, has become a component of the National Spatial Information Infrastructure. It contains information on topographic objects, including the spatial location of objects within the existing national system of geospatial references, characteristics of these objects, cartographic codes, and metadata for the objects. The level of geometrical detail and conceptual generalization objects collected in the topographic database BDOT10k correspond to analogue compilations with a scale of 1:10,000 [4]. It covers $100 \%$ of the country area and contains nine categories of topographic object classes: (1) buildings, structures, and equipment, (2) communication network, (3) waterway network, (4) land cover, (5) land use complex, (6) protected areas, (7) utilities, (8) territorial division units, and (9) other objects providing detailed information on the topography of the area. In legal terms, not only is it a significant component of the spatial information infrastructure, but also a public register intended for the public administration as well as for citizens and entrepreneurs. The topographic database is powered with data from registers maintained by land surveying and cartography services as well as other public institutions. For this reason, sharing, reproduction, dissemination and modification are governed by several regulations.

\section{SHARING THE BDOT10K}

The principal value of the topographic database BDOT10k is the completeness of the standardised and ordered spatial information with a high level of accuracy and detail (literature). All data are subjected to systematic control, ensuring high quality and reliability of information. Unlike other registers, the use of which involves very strict and obligatory cases of the use of the topographic database BDOT10k, it is not a set used obligatorily in the fulfilment of statutory tasks. It is, however, an indispensable set in the fulfilment of numerous public, social, and economic tasks. The basic condition for the efficient use of information originating from the topographic database BDOT10k is to define clear procedures governing the rules and possibilities for its use by both the administration and non-professionals.

The topographic database BDOT10k (topographic object database) is owned by State Treasury. It was established in accordance with provisions of the Land Surveying and Cartographic Law Act (Act of 17 May 1989, Journal of Laws of 2010, No 193, Item 1287) [7]. The responsibility for the maintenance and sharing of the BDOT10k lies with Voivodship Marshals. They are not, however, the only administrators and distributors of these data. The Surveyor General of Poland also holds the power to maintain integrated 
copies of the topographic database BDOT10k. On their behalf, the activities related to the management of the BDOT10k are conducted by the Main Centre for Land Surveying and Cartographic Documentation (CODGIK), whose principal purpose is to conduct material and technical activities aimed at the fulfilment of public tasks assigned to Surveyor General of Poland, to maintain and share databases, and to maintain the system for management of data and services. In accordance with the Act on SDI [6], access for viewing standardised cartographic compilations visualised on the basis of the information stored in the topographic database BDOT10k is free of charge and universal. On the other hand, sharing data from the topographic database BDOT10k is chargeable, and the legal basis for the collection of charges is Article 40a(1) of the Land Surveying and Cartographic Law Act [7]. In certain cases, however, there is a possibility for the exemption of selected entities from the payment of a charge for sharing spatial data from the topographic database BDOT10k. The main purposes behind the possibility for the exemption from the payment of a charge for sharing spatial data are as follows: educational; carrying out research; the fulfilment of statutory tasks in the field of the protection of the internal security of the State and its constitutional order; and the fulfilment of statutory tasks of land surveying and cartographic administrative authorities following the signing of the Act on awarding a public contract including such work. None of the above-mentioned reasons, however, provides for the free-of-charge sharing of data from the topographic database BDOT10k to administrative authorities in order to compile maps supporting the promotion of the areas they manage. Consequently, despite the existence of appropriate data sets, administrative authorities have had to pay, for many years, for the compilation of tourist maps, even though these maps were supposed to be a driver for economic development, i.e. were to serve the common good. However, Article 14 of the Act on SDI (Journal of Laws of 2010, No 76, Item 489) [6] introduced the obligation to share, free of charge, data included in the spatial information infrastructure with other administrative authorities to the extent necessary for those authorities to fulfil public tasks. The Article concerned, as well as the entire Act on SDI [6], came into force in 2010. However, it still took a few more years for this provision to start being understood in terms of the "good" and the needs of urban or regional communities, and not of the needs of the sector, which intended to benefit financially from the data.

Defining a public task expression has proved to be crucial in creating an interpretation of the Article 14 of the Act on SDI (Journal of Laws of 2010, No 76, Item 489) [6]. Nevertheless this issue will be developed further the next article of this series. Unfortunately at the beginning the concept of social interest was understood very narrowly. Therefore, local authorities, despite numerous efforts, could not use, free of charge, reference data from the BDOT10k as a basis for the tourist maps compiled by them with the aim of promoting regions. Currently, however, with the positive development of administrative law in Poland, which increasingly protects the common good (local communities), the term "public tasks" started to be interpreted in a much broader way, which offers the possibility for regarding activities aimed at enhancing the prosperity of local communities as activities of the "public tasks" category. Subsequent papers will broadly describe the issue of understanding the term "public tasks" by land surveying services in relation to the possibility for the free-of-charge use of data from the BDOT10k as reference data for tourist maps compiled with the aim of promoting regions. 


\section{CONCLUSION}

The Land Surveying and Cartographic Law Act along with the Act on spatial information infrastructure impose an obligation on land surveying and cartographic services to prepare standard cartographic compilations based on, inter alia, the data collected in the topographic database BDOT10k. Regulation on the topographic object database as well as the geographic object and standard cartographic map details the process of the development of visualisations of standard cartographic map based on the topographic database BDOT10k. Thanks to the specially developed algorithms, the complex process of cartographic visualisation is an automatic process in which database objects are subjected to symbolisation with the values of these objects' attributes being used with an account taken of various levels of generalisation. During this process, generalisation of the objects for cartographic purposes is also performed, comprising two aspects, namely model generalisation and cartographic generalisation. Thanks to this, high quality topographic maps are compiled which are made widely available (on line) for viewing. Unfortunately, despite the fact that they have been compiled for public money and, inter alia, in order to enhance the prosperity of Polish society, central administrative authorities refused for many years to accept the use of those standard cartographic compilations topographic database BDOT10k as reference information for local tourist maps compiled with the aim of promoting communes or districts. For many years, local governments wishing to promote their region among tourists had to pay huge amounts of money for both the compilation of tourist maps and the reference data used for the compilation of these maps. However, due to the concept of the INSPIRE [5] project along with provisions of the Act on SDI [6], the approach to making spatial data available to local administrative authorities free of charge, to be used by local authorities to disseminate them as reference data for tourist maps, has been changing significantly year by year. A significant change in this regard occurred due to the repeal, on 12 July 2014, of the Regulation of Minister of Regional Development and Construction of 15 May 2001 on the determination of the types of maps, photogrammetric and remote sensing materials constituting the State's land surveying and cartographic resource, in which the dissemination, distribution, and reproduction with intent to disseminate requires a permit, and the mode for granting such permits (Journal of Laws No 56, Item 588) [9]. Due to the changes which followed the repeal of the Regulation, it has become possible to undertake large-scale efforts with the aim to use the topographic database (BDOT10k) for non-standard projects aimed at supporting regions for which tourism is a significant source of income. One algorithm that automates data visualization has been developed within this activity already. This algorithm makes it possible to automate the process of creating thematic maps that support the development Polish selected area [3].

\section{REFERENCES}


[1] Główny Geodeta Kraju, Wytyczne techniczne Baza Danych Topograficznych wersja 1., 2003, GUGiK;

[2] Główny Geodeta Kraju, Baza Danych Topograficznych (TBD) wersja 1.0 uzupełniona załącznik numer 1., 2008, GUGiK;

[3] Leszczyńska M., Cartographic modeling based on an object-oriented and declarative multi-paradigm, Albena, Bulgaria, www.sgem.org, SGEM2014 Conference Proceedings, ISBN 978-619-7105-10-0 / ISSN 1314-2704, June 17-26, 2014, Vol. 1, 481 - 489 pp.;

[4] Olszewski R., Gotlib D., Rola bazy danych obiektów topograficznych w tworzeniu infrastruktury informacji przestrzennej w Polsce, Poland, 2013, ISBN 978-83-2541975-2;

[5] Official Journal of the European Union, Directive 2007/2/Ec of The European Parliament And Of The Council establishing an Infrastructure for Spatial Information in the European Community (INSPIRE), 2007;

[6] Ustawa z dnia 4 marca 2010 r. Ustawa o infrastrukturze informacji przestrzennej. Dz.U. 2010 nr 76 poz. 489;

[7] Ustawa z dnia 17 maja 1989 r. Prawo geodezyjne i kartograficzne, Dz.U. 1989 nr 30 poz. 163;

[8] Rozporządzenie ministra spraw wewnętrznych i administracji z dnia 17 listopada 2011 r w sprawie bazy danych obiektów topograficznych oraz bazy danych obiektów ogólnogeograficznych a także standardowych opracowań kartograficznych Dziennik Ustaw z 2011r nr 279 pozycja 1642;

[9] Rozporządzenia Ministra Rozwoju Regionalnego i Budownictwa z dnia 15 maja 2001 roku w sprawie określenia rodzajów map materiałów fotogrametrycznych i teledetekcyjnych stanowiących państwowy zasób geodezyjny i kartograficzny w których rozpowszechnianie rozprowadzanie oraz reprodukowanie w celu rozpowszechniania wymaga zezwolenia oraz trybu udzielania tych zezwoleń Dziennik Ustaw z 2001r nr 56 pozycja 588; 